\title{
THE EFFECT OF TOURISM IMAGE, SERVICE QUALITY, AND PROMOTION ON RELIGIOUS TOURISM INTEREST IN PRINGSEWU REGENCY
}

\author{
Fauzi ${ }^{\mathrm{a}}$ \\ Tulus Suryanto ${ }^{b}$ \\ Erike Anggraenic \\ Muhammad Nasor ${ }^{d}$ \\ a Postgraduate Masters in Sharia Economics, Islamic State University of Raden Intan Lampung \\ b,c Faculty of Economics and Business, Islamic State University of Raden Intan Lampung \\ ${ }^{d}$ Faculty of Dakwah and Communication, Islamic State University of Raden Intan Lampung \\ Email: drfauzistmikpsw@gmail.coma; tulus@radenintan.ac.id ${ }^{\text {b; }}$; erike@radenintan.ac.id c; \\ nasor@radenintan.ac.id ${ }^{d}$
}

\begin{tabular}{ll}
\hline ARTICLE HISTORY & ABSTRACT \\
& Interest in religious tourism in the Pringsewu Kapubaten, \\
Received: & Indonesia is still relatively low. The purpose of this study is to \\
17 April 2020 & reveal whether there is an influence of tourism image, service \\
Revised: & quality, and tourism promotion on the interest of Muslim \\
2 June 2020 & religious tourism in the Pringsewu district. The research \\
Accepted: & method used is a quantitative method using an accidental \\
2 June 2020 & sampling technique. Data analysis techniques using multiple \\
Online available: & linear regression with the help of SPSS 19.0. The originality of \\
30 June 2020 & the research lies in the sharia economic approach which is \\
Keywords: & carried out to reveal descriptively the results of the influence \\
Tourism Image, & of three independent variables on the interest of Muslim \\
Service Quality, & religious tourism in Pringsewu that have never been revealed \\
Religious Tourism, & by previous studies. The results of the study stated that the \\
Tourism Interests, & percentage contribution of the three variables together \\
Tourism Promotion & amounted to $51,9 \%$. This explains that the image of Muslim \\
*Correspondence: & religious tourism, service quality, and tourism promotion can \\
Name: Fauzi & be a strategy to increase the interest of Muslim religious \\
E-mail: & tourism in the Pringsewu district.
\end{tabular}

drfauzistmikpsw@gmail.com

\section{INTRODUCTION}

The tourism segment in Indonesia until 2019 has developed quite well. Based on the records of the Central Statistics Agency (BPS), "the number of foreign tourist arrivals in 2017 experienced a significant increase that reached, 14.039.799 visits. The number increased by $21,88 \%$ compared to 2016 in the range of 11.519 .275 visits. It is estimated that this number will increase to 156 million in 2020, or represent $10 \%$ of the overall tourism segment." The following data are presented conditions of the Indonesian tourism industry (Residendri.go.id, 2018). 
Table 1

Conditions of the Indonesian Tourism Industry

\begin{tabular}{lcccc}
\hline Provisions & $\mathbf{2 0 1 6}$ & $\mathbf{2 0 1 7}$ & $\mathbf{2 0 1 8}$ & $\mathbf{2 0 1 9}$ \\
\hline Contribution to GDP (\%) & 11 & 13 & 14 & 15 \\
State Foreign Exchange Revenue (Rp trillion) & 172.8 & 182.0 & 223.0 & 275.0 \\
Labor Absorption (million people) & 11.7 & 12.4 & 12.7 & 13.0 \\
Competitiveness Index (WEF) & n.a. & 40 & n.a. & 30 \\
Overseas Tourism Visits (Million) & 12 & 15 & 17 & 20 \\
Nusantara Tourism Travel (million) & 260 & 265 & 270 & 275 \\
\hline
\end{tabular}

Source: Residenri (2018)

The condition of the Indonesian tourism industry creates a strategic opportunity for the development of religious tourism with the characteristics of 'halal tourism' which is a promising tourism concept. The results of the Global Muslim Travel Index (GMTI) study noted that Indonesia ranked first as a popular halal tourist destination in the world with a score of 78 and surpassed 130 other tourist destinations around the world. Meanwhile, Bazazo et al noted that "there is a significant relationship between sharia-based tourism services and satisfaction thereby increasing tourist loyalty (Bazazo et al., 2017)." Not without reason, "tourism's image is a strong magnet to attract foreign tourists (Mano \& Costa, 2015)." In addition, tourists often experience disappointment when visiting tours so they are not interested in visiting for the second time (Michalkó et al., 2015).

As a country with a majority Muslim population, the substance of Islamic values should be the host of their own country. The urgency of the application of the concept of sharia in economic activities such as the empowerment of human and natural resources is a necessity in the midst of industrial progress and global competition (Djakfar, 2017). However, what happens in the middle of the community is that the understanding of the word "sharia" tends to lead to certain religious contexts that have the potential to cause conflict (Sumiati, 2017).

Much deeper, the negative effects that often arise are population polarization, disruption to family household life, and the development of consumptive attitudes (Urbanus \& Febianti, 2017), and "hedonic behavior that is not in accordance with Islamic teachings." (Rinandiyana et al., 2018). Therefore, it is needed the role of government regulations and the National Sharia Board to assist and supervise the tourism sector. The government should show optimism about the possibility of a future recovery of economic prosperity with the development of sharia tourism (Cozma \& Coros, 2017; Satriana \& Faridah, 2018)

According to the $2018 \mathrm{GMTI}$ study, "some important aspects that support the growth of Muslim tourists are an increase in the Muslim population, the development of the middle class, the number of young people, easy access to tourist information, mushrooming Muslim-friendly facilities, and tours in Ramadan." (Mastercard \& Crescentrating, 2018). In addition, "the role of human resources, media, research and development, events, state capabilities, public and government support, marketing strategies, and infrastructure are vital requirements. 
Furthermore, from the perception of experts, public and government support, marketing strategies, and human capital (Borzooei \& Asgari, 2013).

The real opportunity of religious tourism destinations and the potential of tourism objects owned are not wasted by the Pringsewu Regency Government. Therefore, local governments need to start mimicking the concept of tourism which is based on the sharia concept. This can be done by the local government by empowering the potential of the Pringsewu district area effectively and efficiently.

Religious tourism is one that has the potential for this. In addition to the APBD objectives, religious tourism is intended to increase literacy and religious education facilities for the development of tourist behavior that has good character and morality. All of the above conditions will make it possible to increase employment and economic growth (Satriana \& Faridah, 2018), improve tourism performance (Sabon et al., 2018), increase the competitiveness of tourist destinations with a multidimensional concept that includes economic, social, cultural, politics, technology and the environment (Dimoska \& Trimcev, 2012), and mapping the potential of tourism objects in order to maximize the existing tourism potential (Niasari, 2017).

Lampung Province is known as an area with potential and tourist destinations, now a magnet for tourists. Of the approximately 15 million inhabitants of Jakarta, two million of its citizens travel to some attractions in Java and Sumatra including Lampung. If one person carries one million rupiahs, this means around 200 billion rupiahs spent in Lampung. Lampung has a local budget (APBD) of around 7 trillion rupiahs (Nota keuangan, 2020).

Table 2

Number of Nusantara and Foreign Tourist Visits of Lampung Province from 2012 to 2017

\begin{tabular}{cccc}
\hline Year & Traveler Archipelago & Foreign Tourists & Total \\
\hline 2012 & 2.581 .165 & 58.205 & 2.639 .370 \\
2013 & 3.392 .125 & 75.590 & 3.467 .715 \\
2014 & 4.327 .188 & 95.528 & 4.422 .716 \\
2015 & 5.370 .803 & 114.907 & 5.485 .710 \\
2016 & 7.381 .774 & 155.053 & 7.536 .827 \\
2017 & 11.395 .827 & 245.372 & 11.641 .199 \\
\hline
\end{tabular}

Source: Lampung Provincial goverment (2017)

Table 2 shows, from 2013 to 2017, the number of tourist arrivals in Lampung Province continued to increase. In this case, the number of tourists visiting Lampung Province increased which occurred again in 2015 amounted to 5.645.710 and 2016 which amounted to 7.536.827. Experience an increase from 2015 to 2016 by 33,49\%. The number of Lampung tourists increased again in 2017, recorded 11.641.199 people or an increase of $54,45 \%$ compared to the previous year.

Table 3

Total Tourism Sector Revenue in Lampung Province in 2011-2018

Year Tourism sector income Increase Percentage




\begin{tabular}{llll}
\hline $\mathbf{2 0 1 1}$ & Rp27.013.204.794 & - & - \\
$\mathbf{2 0 1 2}$ & Rp32.195.531.029 & Rp5.182.326.235 & $19 \%$ \\
$\mathbf{2 0 1 3}$ & Rp38.673.529.071 & Rp6.477.998.042 & $20 \%$ \\
$\mathbf{2 0 1 4}$ & Rp46.605.823.538 & Rp7.932.294.467 & $21 \%$ \\
$\mathbf{2 0 1 5}$ & Rp51.876.105.748 & Rp5.270.282.210 & $11 \%$ \\
$\mathbf{2 0 1 6}$ & Rp57.345.654.454 & Rp5.469.548.706 & $10 \%$ \\
$\mathbf{2 0 1 7}$ & Rp61.345.443.344 & Rp3.999.788.890 & $7 \%$ \\
$\mathbf{2 0 1 8}$ & Rp67.452.543.543 & Rp6.107.100.199 & $9 \%$ \\
\hline
\end{tabular}

Source: Bank Indonesia (2019)

Table 3 above shows that the increase in income from the tourism sector continues to rise in line with the development of tourist destinations, and the many social media that offer attractive tourist destinations.

Pringsewu's economic growth, from year to year, continues to experience a fairly good development. In 2016, the Gross Regional Domestic Product (GDRP) was $5,80 \%$ and in 2017 , it increased to $7,10 \%$. At the end of 2019 , the growth was increasing. It happened because the economic structure of Pringsewu, which was dominated by agriculture, forestry, and fisheries, gave a large contribution to the GDRP (Pemerintah Provinsi Lampung, 2017).

In the grave complex KH. Ghalib in Pringsewu and $\mathrm{KH}$. Ahmad Rais Abdillah in Ambarawa was very busy to be visited by pilgrims, especially in certain months namely before the fasting month of Ramadan, the month of Muharom, the month of Rabiul Awal (Maulid), and the month of Rajab. Most came from West Java, Jakarta, Banten, Jambi, South Sumatra, Bengkulu, and domestic pilgrims in Lampung Province.

This research wants to answer the main problem of religious tourism in the Pringsewu District. Community interest in religious tourism is very low. Therefore, there is a need for further assessment. If the community's interest is low, it is feared that not only the potential for visiting religious tourism will not be effectively empowered but the literacy and educational goals will not be maximized. It also includes the importance of religiosity in understanding the satisfaction and behavior of Muslim customers as a strategy in facing the challenges of modernizing world tourism. Previous research has not revealed in depth the relationship between tourism imagery, service quality, and tourism promotion to the interest of Muslim religious tourism, especially in Pringsewu District. Based on the data that has been presented, it can be seen that the great potential of religious tourism in Pringsewu District is significant enough to be developed and is expected to be able to improve the economic level of its people. This has also been supported and appreciated by the local government of Pringsewu district.

An interesting finding is related to the interest of visiting tourists to visit religious tourism places, namely that tourist motives have shifted from pure religious motives to secular tourism motives. This identifies that emerging new perspectives from visiting interests are not merely religious, even those who visit religious places are those who come from different religions and cultures. This finding is expected to contribute to Pringsewu's regional government strategy in realizing religious tourism 
through tourism image, service quality, and promotion adjusted to Law No. 33 of 2014 and according to the National Sharia Council Fatwa (MUI).

This research is limited to discussing the image of tourism, service quality, and promotion carried out to attract Muslim religious tourism interests in Pringsewu District. The research study is located in Muslim religious tourism in the $\mathrm{KH}$. Ghalib in West Pringsewu Village Pringsewu District Pringsewu Regency and KH. Ahmad Rais Abdillah in Pekon Ambarawa, Ambarawa District, Pringsewu Regency.

\section{LITERATURE REVIEW}

\section{Sharia Tourism}

According to Priyadi, "There are several characteristics that mark a tourism product, as follows; 1 ) tourism products or products cannot be moved or transferred to other location/regions; 2) production and consumption are carried out at the same time; 3) tourism products do not use physical measurement standards but use service quality standards based on certain criteria or characteristics; 4) travelers or the tourism consumers cannot try previous product samples, even do not know or test previous products; 5 ) the results of tourism products are dominated by the role of human resources; and 6) business products are businesses that contain risk (Priyadi, 2016).

In the context of Islamic Economics, tourism is a human effort to obtain a halal fortune, obtain useful knowledge, safar or take a religious journey that has the main goal of obtaining the blessing of Allah SWT (Syahriza, 2014). Tourism is valued as an individual's belief and as a source of socio-economic development (Jafari \& Scott, 2014). Sharia-based tourism is a concept of developing Islamic economics based on the Qur'an and As-Sunnah (Syahriza, 2014).

In understanding Islam, tourism should be linked to knowledge and knowledge. At the beginning of Islam, there has been a very grand journey to seek knowledge and spread it. Until Al-Khatib Al-Bagdady wrote the famous book "ArRihlah Fi Thalabil Hadith", he collected stories of people who traveled only to gain knowledge and search for just one hadith. Ikrimah said "AsSaa'ihuna" they are knowledge seekers. Although the interpretation is correct according to the majority of salaf scholars that what is meant by "As-Saaihin" are people who fast. Tours with the aim of taking lessons and warnings. In the Qur'an, there are commands to walk on the face of the earth in several places surah al-An'am: 11 and al-Naml: 69. Sa'far or tours to contemplate the beauty of God's creation, enjoy the beauty of the natural universe as a booster of the human soul to strengthen faith in the oneness of Allah and motivate to fulfill the obligations of life as mentioned by Allah in the Qur'an.

According to Hutabarat, the role of tourism is first, the role of the economy as a source of foreign exchange for the country. secondly, the social role as job creation and business opportunities. Third, the role of culture as a forum to promote and preserve culture, tourism, the arts, and others (Zumli, 2018). 
Sharia tourism is a product that gives different values to tourists both Muslim and non-Muslim so that the impression of a comfortable and better tour can be obtained by tourists (Gabdrakhmanov et al., 2016). "The image of a tour will greatly affect the decision of individuals/group to visit and travel to a particular area." (Nassar et al., 2015). Even for visitors who frequently visit a tourist site, the tourism image is in the first position of decision making compared to the attraction through promotion (Wu \& Zheng, 2014).

The quality of tourist services is the construction of four dimensions. The structural findings state that service quality, tourist image, and destination promotion mediate international tourist visiting decisions. In addition, there are six dimensions of value perceived by Muslim tourists, consisting of quality, price, emotional value, the value of Islamic physical attributes, and the value of Islamic nonphysical attributes. Likewise, the quality of the trip and the value of the trip (Sudigdo et al., 2019) as well as the existence of available worship facilities (Battor, 2017). Overall these dimensions must be supported by technological developments and the use of science and technology both in governance and operationalization (Nuri, 2018).

Implementation of Tourism Based on Sharia Principles based on the MUI Fatwa No: 108 / DSN-MUI (X) 2016. In the General Provisions in this fatwa what is meant is First about the definition of tourism: 1) tourism is a travel activity carried out by someone or a group of people by visiting a particular place for recreational purposes, personal development, or learning the uniqueness of a tourist attraction that is visited in a temporary period; 2 ) sharia tourism is tourism in accordance with sharia principles; 3 ) tourism is a variety of tourism activities and is supported by various facilities and services provided by the community, entrepreneurs, government and local governments; 4) sharia tourism is in accordance with sharia principles; and 5) sharia tourism destinations are geographical areas within one or more administrative regions in which there are tourist attractions, religious and public facilities, tourism facilities, accessibility, and communities that are interrelated and complement the realization of tourism in accordance with sharia principles, and tourists are people who travel (National Sharia Council Fatwa, 2016).

Then further on all sharia tourism activities, namely: 1) Sharia Travel Bureau (Biro Perjalanan Wisata Syariah (BPWS)) is a commercial business activity that regulates, and provides services for a person or group of people, to travel with the main purpose of traveling in accordance with sharia principles; 2) tour guide is a person who guides in sharia tourism; 2) tourism entrepreneurs are people or groups of people who carry out tourism business activities; 3 ) sharia hotel business is the provision of accommodations in the form of rooms in a building that can be equipped with food and drink services, entertainment activities and or other facilities on a daily basis with the aim of obtaining profits that are run according to sharia principles; and 4) sharia hotel business criteria is the formulation of qualifications and/or 
classifications that cover aspects of products, services, and management, and the Therapist is the party conducting spa, sauna, and/or massage (National Sharia Council Fatwa, 2016).

Akad (Agreements) in sharia tourism activities, namely: 1) the ijarah contract is a contract for the transfer of the right to use a product or service within a certain time with payment or wages; 2) akad wakalah bil ujrah is a contract of empowerment accompanied by an ujrah from sharia hotels to BPWS to conduct marketing, and ju'alah contract is a promise or commitment (iltizam) for the company to provide certain rewards (iwadh/ju'l) to workers ('amil) for the achievement of results (achievement/natijah) determined from a job (object of the contract ju'alah) (Fatwa of the National Sharia Council, 2016).

The legal provisions for organizing tourism based on sharia principles may be carried out on condition that they follow the provisions contained in this fatwa. Organizing tourism must avoid polytheism, disobedience, disobedience, tabdzir/israf, and munkar, and create benefits and benefits both materially and spiritually. Whereas the provisions of sharia hotels where hotel managers and employees are required to wear clothing according to Islamic sharia and sharia hotels are required to have service guidelines to guarantee services in accordance with sharia. In terms of spas, saunas, and massages, the human resources of male therapists only serve male consumers and female therapists are only for female consumers (National Sharia Council Fatwa, 2016).

Similarly, the provisions of Islamic travel agencies have travel guides that prevent from shirk, khurafat, immorality, adultery, pornography, porno-action, alcohol, drugs, and gambling. On the provisions of Islamic tour guides, human resources guides of Islamic tourism must understand and implement the value sharia values in their duties, have good character, communicative, friendly, honest, and responsible. In this provision, sharia tour guide human resources are required to have work competencies according to professional standards as evidenced by a competency certificate (National Sharia Council Fatwa, 2016).

\section{Tourism Imagery}

According to Sach (2010), "Image is knowledge about us and attitudes towards us who have different groups. Image is the impression, feeling, and image of the public towards the company. Impressions intentionally created from an object, person or organization." (Sach, 2010). Soemitra and Ardianto (2007) define an image as a picture of reality and not necessarily in accordance with reality, the image is the world according to perception. understanding of the experts above, the image can be interpreted as a picture obtained by the surrounding environment or other parties as a result of his experience and knowledge of an object (Soemitra \& Ardianto, 2007).

In general, the dimensions of tourism images are used to measure the variable image of a tourism destination. Consists of nine indicators as follows; a) The 
environment is a situation in and around tourist objects; b) Natural tourism is a natural condition surrounding a tourist attraction; c) Events and entertainment, namely the variety of activities presented at the location of the tourist attraction; d) Infrastructure as a tourist attraction supporting facility; e) Accessibility, namely smoothness or ease of access to tourist destination locations; f) Relaxation is a condition where a tourist attraction can help calm the mind and nourish the body and the price and value, which is the cost that must be incurred while in a tourist attraction (Paludi, 2017).

Meanwhile, Witt and Luiz (1989) state that four attractions motivate tourists to make a tour of an area, namely; 1 ) natural attractions include natural landscapes, natural scenery, oceans, climate, and beaches; 2) building attractions include buildings and historic architects both modern and archeological; 3) managed visitor attractions include industrial estate sites; and 4) cultural attractions include theater, museums, historic sites, customs, religious places and historical events (Witt and Luiz, 1989).

\section{Quality of Travel Services}

Quality is a dynamic condition that affects products, services, people, processes, and environments that meet or exceed expectations. So that the definition of service quality can be interpreted as an effort to meet the needs and desires of tourists and the accuracy of its delivery in balancing tourist expectations (Tjipto \& Gregorius, 2010). Whereas Service is any action or activity that can be offered by one party to another party, which is basically intangible and does not result in any ownership (Kotler \& K., 2010). Quality of service tourist attractions are the basis for tourism. It can be concluded that the quality of service of attractions is everything that can make tourists want to be back at a tourist spot or visit these attractions because of a feeling of satisfaction with the services that are obtained at these attractions as well as the uniqueness and high value, which is the destination of tourists coming to a certain area. Basically, the notion of service quality starts with the company's efforts to meet customer expectations, which consist of three types, namely: 1) will expectation which is the level of service performance expected to be obtained by customers; 2) should expectation which is the level of service performance that should be obtained by the customer; and 3) ideal expectation is the ideal level of service performance obtained by customers.

Customers compare service expectations (expected service) with perceived services, so service quality will depend on the company's ability to meet customer expectations. According to Parasuraman et al. (1988), the main difference between the two variables is that service quality results in customer satisfaction. Parasuraman et al. (1988) and Gwinner et al. (1998) explain, "Customer satisfaction is a more specific measure of each service transaction or service interaction that occurs between companies and customers and is short-term, so that service quality is an 
attitude that is formed on the results of a comprehensive evaluation of the company's service performance in the long run." The very famous service quality dimension model is the result of research conducted by Parasuraman, et al. establishes five dimensions of service quality. The five dimensions are reliability, responsiveness; assurance, empathy, and tangibles.

\section{Tourism Promotion}

Promotion is a type of communication that provides an explanation and convinces prospective tourists about goods and services with the aim of gaining attention, educating, reminding, and convincing potential tourists (Alma, 2010). The promotion of well-designed tourist attractions will add to the original acceptance of the area, and encourage a multiplier process of locality economic development around the tourist destination. As for the steps to develop tourism by promoting several stages, namely: 1 ) identifying the target market; 2 ) determine the purpose of communication; 3) designing messages; 4) complete communication channels; 5) determine the amount of the budget and promotional tools; and 6) measuring the results of promotions and implementing coordination and communication processes (Kotler \& K., 2010).

To be able to compete in the tourism industry, promoting tourism in certain destinations is a must. To be successful, marketing must constantly present the best image of a tourist destination while creating a wide-scale interest in various management strategies as follows 1) form a tourism partnership to help maximize marketing and reach a wider and more promising audience for specific goals. The support of partners who already have a wide network coverage helps save promotion costs and will benefit both parties; 2) organizing trade shows gives destination access to every travel and tourism supplier. Trade shows bring together every aspect of the travel industry in one place and give time to interact and become a new opportunity to develop themselves. They will also attract the attention of the media, public participants, and travel agents and of course their millions of customers; 3 ) take out advertisements in trade publications to attract the attention of sellers of travel around the country to the product they have. Create a brand for tourism purposes and find the identity of the destination and give an interesting description so that tourists are interested in visiting just by looking at the advertisements that have been published. Placing travel ads in a smart and targeted way is the last part; 4) sponsored events and prizes that match tourist destinations and create a level of prestige for the brand. Sponsors are available in all shapes and sizes. Through television shows will also have many extra benefits from local media coverage. In other words, the potential for tourism advertising will increase as sponsorship costs increase; and 5) utilizing social media allows destinations to connect with target markets by utilizing brands that are already known to consumers (Morello, 2019). 


\section{Tourism Interests}

Buying interest is part of the behavioral component in the attitude to consume. According to Kinnear and Taylor (2003), "Buying interest is part of the component of consumer behavior in consuming attitudes, the tendency of respondents to act before buying decisions are actually implemented." Interests have special characteristics and characteristics as follows: 1) interest are personal (individual), there is a difference between someone's interests and others; 2) interest has a discriminatory effect; and 3) closely related to motivation, influencing and influenced by motivation and interest is something that is learned, not innate and can change depending on needs, experience, and fashion.

The factors that include interest are divided into two namely physical, social, and selfish needs and experience needs (Jahja, 2011). Interest is described as a person's situation before taking action that can be used as a basis for predicting the behavior or action, buying interest is related to consumers' plans to buy certain products and how many units of product are needed in a certain period, it can be said that buying interest is a statement mentality of consumers who reflect the plan to purchase a number of products with a particular brand.

Interest in buying can be identified through the following indicators: 1 ) transactional interest, namely the tendency of a person to buy a product; 2)interest referrals, i.e. one's tendency to refer products to other people; 3) preferential interest, that is an interest that describes the behavior of someone who has the main preference on the product; and 4) explorative interest, this interest describes the behavior of someone who is always looking for information about the product of interest and looking for information to support the positive qualities of the product (Ferdinand, 2006). Furthermore, the results of Kotler, Bowen, and Makens' research explain that there are two factors that influence a person's buying interest in the decision-making process, namely the unexpected situation and the attitude towards others (respect to others).

\section{RESEARCH METHODS}

The place of this research was conducted in the Muslim religious tourism area of the Tomb of KH. Ghalib in West Pringsewu Sub-District, Pringsewu District, and the Tomb of KH. Ahmad Rais Abdillah in Pekon Ambarawa, Ambarawa District, Pringsewu Regency, Lampung Province. The research has been carried out from the beginning of December 2019 until it is expected to be completed by the end of February 2020. This research has a wide scope, considering that the influencing variable consists of four sub-topics, namely the image of tourism, service quality, tourism promotion, and interest visit. By using a descriptive statistical design to explain the findings which will be analyzed using multiple linear regression. Multiple linear regression can express the influence of both partially and simultaneously the independent variables on the dependent variable so that it is expected to provide valid research results in 
accordance with the background of the problem and research objectives. The scope used is based on the study of Islamic economics system literature and Islamic economic empowerment. Sharia tourism studies in literature will explore the issues studied and provide based on sharia principles. The research model is made to explain in detail the effects and relationships between research variables. And the theory raised is used to support the results of research.

Judging from the nature of this study, including descriptive research, research that explains or describes the characteristics of the personal, an event, and situation that occurs around the researcher (Sekaran \& Bougie, 2013). The associative quantitative method was carried out to determine the magnitude of the influence of the dependent variable on the dependent variable using numbers and analyzed using statistics with the help of SPSS 19.0 (Sugiyono, 2009). The research uses an accidental sampling technique, which is a technique of determining samples based on coincidence, ie anyone who incidentally can be a sample criterion for research if deemed suitable with the data source. Data can mean the fact of an object that is observed either in the form of numbers or words that are used as material for drawing conclusions (Hadi, 2015). Based on the sample formulation, the number of samples to be taken ie between the minimum and maximum samples of the study totaling 300 respondents was taken based on that number. Sampling is based on a minimum sample size of five times a total of 30 question indicators that is 150 and a maximum of ten times a total questions that exist is 300 .

Based on the data obtained that the great potential of religious tourism in Pringsewu District is quite significant to be developed and is expected to be able to improve the economic level of its people. This has also been supported and appreciated by the local government of Pringsewu district. Therefore, researchers sought to reveal the influence of the three independent variables on religious tourism interest so that people's interest in religious tourism could increase so that it was expected that religious tourism visits to Pringsewu District would increase.

\section{RESULT AND ANALYSIS}

\section{Overview of Research Objects}

Pringsewu Regency has an area of $625 \mathrm{~km}^{2}$, has a population of 475,353 inhabitants consisting of 126 Pekon and has around five regencies spread over nine Districts. Namely Pardasuka Subdistrict, Ambarawa Subdistrict, Pagelaran Subdistrict, North Pagelaran Subdistrict, Pringsewu Subdistrict, Gading Rejo Subdistrict, Sukoharjo Subdistrict, Banyumas Subdistrict, and Adiluwih Subdistrict. Vision: Competitive, Harmonious, and Prosperous District. In history, it is recorded that the Pringsewu district is part of the administrative area of the South Lampung Regent's Assistant for the City of Agung and became part of the Dati II Tanggamus Regency based on Law No. 2 of 1997 until it officially became an autonomous region named 
Pringsewu District through Law No. 48 of 2008 which was inaugurated by the Minister of Home Affairs on 3 April 2009.

To support the tourism sector, the local government through investment conservation is developing business expansion in urban Pringsewu such as restaurant construction, availability of transportation, entertainment facilities, and shopping and culinary tourism typical of Pringsewu district. This certainly shows that the business and tourism climate in Pringsewu district is very conducive. Not only able to attract tourists, but also motivate the community to become entrepreneurs so as to improve the welfare and local wisdom to be better. "The National Dialogue which is held every year is one of the activities organized by the Religious Harmony Forum and the Pringsewu Interfaith Youth Forum in order to become a means to equalize the vision and mission and perceptions to build and maintain the integrity of the nation and state. This is a great capital and strength in developing the country, especially in Pingsewu district which is based on the spirit of unity and unity as well as national insight based on the Pancasila and the 1945 Constitution." (Pringsewu go.id, 2018). As an area that has tourism objects with good prospects to be developed, some tourism potentials in Pringsewu Regency have not been explored to the full potential so they still need support from stakeholders for the future to be more optimal.

\section{Muslim Religious Tourism in the Pringsewu District}

Based on field surveys and data in 2017 the average number of visitors to religious tourism objects is 4.192 people. In this study, the object of research is the religious tourism of Kyai Haji Ghalib Grave located in West Pringsewu and KH. Ahmad Rais Abdillah on the Bukit Dirham Pekon Ambarawa Ambarawa District Pringsewu Regency. According to historical records, KH. Ghalib was a scholar and a freedom fighter and a great scholar. He was buried not far from his pesantren precisely in West Pringsewu Public Cemetery. While KH. Ahmad Rais Abdillah is a great scholar who founded the Islamic Boarding School Foundation Tahfidzul Quran Mathlaul Huda in Ambarawa sub-district.

The grave of $\mathrm{KH}$. Ghalib and the tomb of $\mathrm{KH}$. Ahmad Rais Abdillah was visited by pilgrims both from outside the Lampung region and even from abroad, especially when entering the holy month of Ramadan. Tomb site is one of the centers of religious pilgrimage tourism. Unfortunately, it is quite difficult to find his historical record. Therefore, so that the next generation of the nation knows of the great people who contributed to the nation during his lifetime and can become role models, there must be a historical track record. In addition to historical records, facilities and infrastructure have not been sufficiently supportive especially access to locations that are still under development. Some visitors seem to still find it difficult to find the needs they need during the visit. For example, the availability of souvenirs, and also a resort that provides a variety of food and drink needs. In its development, the Pringsewu district government wants to develop the tomb of $\mathrm{KH}$. 
Ghalib and $\mathrm{KH}$. Ahmad Rais Abdillah as one of the religious tourism destinations. It also aims as a form of respect during his lifetime.

Based on the Coefficient output table we can get the multiple linear regression equation as follows:

Table 4

Summary Output model Summary, Anova table, and Coefficient

\begin{tabular}{lccc}
\hline \multicolumn{1}{c}{ Variable } & Regression coefficient & T count & Sig. \\
\hline Constanta & 2,129 & &, 001 \\
Imagery_Tourism & 0,063 & 3,513 &, 000 \\
Service_Quality &, 315 & 7,301 &, 000 \\
Tourism_Promotion &, 141 & 6,463 & \\
Anova table & 0,000 & & \\
F count & 106,616 & & \\
R & 0,721 & & \\
R Square &, 519 & & \\
df (N1) & 3 & & \\
df (N2) & 296 & & \\
\hline
\end{tabular}

Source: SPSS 19.0 Processed Data

a. The formula for the regression equation in this analysis is $Y=2,129+0,063 X_{1}+$ $0,315 X_{2}+0,141 X_{3}$. And the coefficient value $F_{\text {count }}(161,565)>F_{\text {table }}(2,65)$. This means that the regression model that is built is valid as a predictor model.

b. Multiple Correlation Analysis (R)

Based on the output summary model table, it is explained that the correlation coefficient value is 0,721 which shows that there is a strong relationship between the three independent variables (tourism image, service quality, and tourism promotion) and the dependent variable.

c. Determination Analysis (R2)

Based on the model summary table the results of R2 (R Square) show a value of 0,519 or $51,9 \%$. This explains that the percentage contribution of the influence of the independent variable on the dependent variable is $51,9 \%$. While the remaining $48,1 \%$ is influenced by other variables not included in the research model.

\section{Research Hypothesis}

The influence of tourist imagery on Muslim religious tourism interest in Pringsewu District

From the summary output table, it can be seen that the value of the Tourism Image variable $(X 1)$ is $0,001(p<0.05)$ so that the hypothesis is accepted. This means that the tourism image variable (X1) significantly influences tourism interest in Pringsewu district. Based on the multiple linear regression equation explained that if the variable quality of service (X2) and tourism promotion (X3) the value is fixed and the image of tourism (X1) has increased $1 \%$, then tourism interest $(Y)$ will decrease by 0.063 . The positive value coefficient occurs a positive relationship between the image of tourism (X1) with tourism interest (Y), the more the image of tourism increases, the more interest in Muslim religious tourism in Pringsewu district. 
Analysis of the effect of service quality on Muslim religious tourism interest in Pringsewu District

From the summary output table, it can be seen that the value of the service quality variable $(X 2)$ is $0,00(p<0.05)$ so that the hypothesis is accepted. This means that the service quality variable $(X 2)$ significantly influences tourism interest in Pringsewu district. Service coefficient variable regression coefficient $(X 2)$ of 0,315 ; it means that if the tourism image variable $(\mathrm{X} 1)$ and tourism promotion (X3) value is fixed and the quality of service $(X 2)$ has increased by $1 \%$, then tourism interest $(Y)$ will increase by 0,315 . The positive value coefficient shows a positive relationship between service quality $(\mathrm{X} 2)$ and tourism interest $(\mathrm{Y})$, the more the quality of service $(\mathrm{X} 2)$ increases the tourist interest $(\mathrm{Y})$.

The influence of tourism promotion partially on the interest of Muslim religious tourism in Pringsewu District

From the output summary table, it can be seen that the value of the tourism promotion variable $(X 3)$ is $0,00(p<0.05)$ so that the hypothesis is accepted. This means that the tourism promotion variable (X3) significantly influences tourism interest in Pringsewu district. The regression coefficient of the tourism promotion variable (X3) is 0,141 ; it means that if the tourism image variable (X1) and service quality $(X 2)$ value are fixed and tourism promotion $(X 3)$ has increased $1 \%$, then tourism interest $(Y)$ will increase by 0,141 . The positive-value coefficient occurs a positive relationship between tourism promotion $(\mathrm{X} 3)$ and tourism interest $(\mathrm{Y})$, the more tourism promotion $(\mathrm{X} 2)$ increases the tourism interest $(\mathrm{Y})$.

The influence of tourism image, service quality, and tourism promotion partially on the interest of Muslim religious tourism in Pringsewu District

a. Based on Table 4, it is known the value of Sig. of 0,000. Because the value of Sig. $0,000<0.05$, it can be concluded that $\mathrm{Ho}$ is rejected because the sig value contained in the Anova table, the independent variable shows the Sig. which is smaller than 0,005 . So it can be said that there is a significant influence between the image of tourism, the quality of service, and simultaneous tourism promotion on the interest of Muslim religious tourism in Pringsewu District.

b. Based on the comparison of the calculated $F$ value with $F$ table is $106,616>F$ table 2,65 , as the basis for decision making in the $F$ test revealed that there is a significant influence between tourism image, service quality, and tourism promotion simultaneously on the interest of Muslim religious tourism in Pringsewu District.

The Influence of Tourism Imagery, Services, and Promotion on travel interests 
The results of this study indicate that there is an influence of tourist image, service quality, and promotion simultaneously on tour interests. Travel interest is part of the behavioral component in the attitude of visiting tourist destinations. Therefore, to increase interest in traveling can be done through various things, such as improving the image, tourism services, and promotion. The results of this study are basically in accordance with research conducted by Kinnear and Taylor interest in buying products including tourism products is part of the component of consumer behavior in attitudes and tendencies to act before buying decisions are implemented, which are entirely influenced by the image, service, and promotion (Husein, 2005).

Interests have special characteristics and characteristics because interests are personal (individual), so there is always a difference between someone's interest and someone else's. Someone's interest to visit tourist destinations can be described as a person's situation before making a visit which can be used as a basis for predicting tourist behavior. Travel interest is related to tourists' plans to visit certain tourism objects and how many times they want to visit these destinations, it is very dependent on the image that is emitted by the destination, the quality of service, and the promotion to be visited. The quality of service of the parties concerned and the promotion carried out by the manager and the local government also greatly influences the interest in traveling.

Tourist interest can be understood from the tendency of tourists to visit a destination. When they have a high interest in a tourist attraction, then they will refer to the tourist location to others. Tourists will also always look for information about the destinations they are interested in and look for information to support the positive characteristics of these tourist destinations (Ferdinand, 2006). Here, the image of tourism and the quality of services, as well as promotion, play a major role in the process. People who are satisfied with the tourist sites visited will always recommend to others through the WhatsApp group, Facebook, Instagram, and other social media. It can be a free advertisement for these tourist destinations. Conversely, if the image is bad, the quality of service is rushed, moreover, no promotion is disseminated massively, then the interest of tourists to visit tourist destinations is low.

The results of this study also strengthen the research of Kotler et al. (2014) which explains that three factors influence a person's buying interest in the process of making a purchase decision, namely image, service, and promotion. Likewise, one's interest in consuming a tourism product will be strongly related to these three things, image, service quality, and promotion (Kotler et al., 2014).

Of the three aspects, the factor that most influences interest in traveling is the image of tourism, because it provides the largest contribution. Therefore, when wanting to increase the interest in traveling the community, the most important aspect to be improved is the aspect of tourism imagery. The image of the tour must be maintained, either through the process of testimony, impression construction, 
and other strategies that can maintain and enhance a positive image of the various existing tourist destinations.

Service quality must also not be forgotten, because service quality is a dynamic condition that can affect one's interest in the product. Thus, a better quality of service can increase the interests or desires of tourists (Tjipto \& Gregorius, 2010). Likewise, actions or activities that can be given by managers to tourists will be able to increase interest in traveling (Kotler \& K., 2010).

The quality of tourist attraction services is the basis for the continuity of the tourism business. The better the quality of service of attractions with everything can make tourists want to be back in these tourist attractions. This condition can be said that their interest is high. They also have the interest to re-visit these tourist attractions because they feel satisfied with the services obtained at these attractions. They also want to return to the location on another occasion by inviting other friends and relatives because they get the satisfaction and uniqueness and high value of the destinations that become tourist destinations.

Quality of service relies on the destination manager's business to meet customer expectations, by getting will expectation, tourists will feel the performance of the services obtained can meet customer expectations. The tourists can also get the expectation which is the level of service performance obtained by visitors to tourist destinations. In addition, tourists can also get the ideal expectation which is the level of performance of the ideal service obtained by visitors while in tourist attractions.

The narrower the stereotypes between expectations and reality of service quality, the higher their interest in returning to visit. The tourists will compare the expected service with the service received, so the quality of service will greatly affect the interests and expectations of visitors. Service quality generates customer interest and satisfaction (Parasuraman et al., 1988). Customer interest and satisfaction is a more specific measure of any service transactions or service interactions that occur between tourist destinations and long-term visitors, so that service quality is an attitude that is formed on the results of a comprehensive evaluation of the service performance of tour destination managers in the long run (Gwinner et al., 1998).

Quality of service results in customer satisfaction with the company. The service quality dimension model that is very well known and in accordance with the results of this study is the result of a study that establishes five dimensions of service quality, namely reliability, responsiveness, assurance, empathy, and tangibles (Parasuraman et al., 1988). However, tourist behavior can also be quickly attracted to advertising or promotion with a note that the tourist attractions promoted have a good image. The image of tourism is influenced by reference groups, family, friends, social media that develop in the community, including virtual society. The image of tourism that is influenced by the quality of tourism products can affect travel interest. The image of tourism does not use physical measurement standards but 
instead uses the assessment standards of the majority of visitors, so it needs to be built and maintained so that the whole community but has a high interest to visit these tourist destinations.

The image of tourism that is considered good by visitors will have a positive impact on increasing the number of tourist visits. The image of tourism as knowledge of a tourist location makes an impression, a feeling, a picture of the public towards a tourist destination (Wu \& Zheng, 2014). Impressions that are intentionally created from a tourist attraction can be constructed by previous visitors as a result of their experience and knowledge of an object (Sach, 2010). The image of tourism as a picture of the reality of tourist destinations, according to the perceptions of visitors who have visited these tourist destinations (Soemitra \& Ardianto, 2007).

\section{CONCLUSION}

Based on the results of the analysis and discussion can be concluded as follows. Based on the results of the analysis it was found that the percentage contribution of the influence of the independent variable on the dependent variable was $49.1 \%$. While the remaining $49.1 \%$ is influenced by other variables not included in the research model. The results of the study can provide benefits for the Pringsewu District Government which specifically can improve the image of Muslim religious tourism. Given that the results of the study, the value of the image of Muslim religious tourism in the Pringsewu district is still low in the eyes of respondents. Interest in Muslim religious tourism can be increased by continuously improving the quality of services and promoting tourism. Research is expected to be developed into a broader study with empirical evidence that is continually updated so that later new factors will emerge that could potentially become scientific research that can be beneficial for the development of science. This research can contribute to future research on how to increase the potential of Muslim religious tourism in various regions. From the results of the discussion, it can be understood that the principles of sharia can be implemented on the three independent variables (tourism image, service quality, and tourism promotion) to increase the interest of Muslim religious tourism in Pringsewu District.

\section{REFERENCE}

Alma, B. (2010). Kewirausahaan (Edisi Revisi). Alfabeta.

Bank Indonesia. (2019). Kajian Ekonomi Regional: Laporan Perekonomian Provinsi Lampung Periode Mei 2019. Www.Bi.Go.Id.

Battour, M. (2017). Halal tourism and its impact on-non-Muslim tourist' perception,trip quality and trip value. International Journal of Culture, Tourism and Hospitaly Research 00-00. https://doi.org/10.1108/IJCTHR-02-2017-0020

Bazazo, I., Elyas, T., Awawdeh, L., Faroun, M., \& Qawasmeh, S. (2017). The Impact of Islamic Attributes of Destination on Destination Loyalty via the Mediating Effect of Tourist Satisfaction. International Journal of Business Administration, 8(4), 65. 
https://doi.org/10.5430/ijba.v8n4p65

Borzooei, M., \& Asgari, M. (2013). Establishing a Global Halal Hub: In-Depth Interviews. International Journal of Academic Research in Business and Social Sciences, 3(10). https://doi.org/10.6007/ijarbss/v3-i10/288

Cozma, A. C., \& Coros, M. M. (2017). Tourism Development in Rodna Mountains National Park: the Public Administration, a Key Stakeholder. Revista de Turism: Studii Si Cercetari in Turism, 0(24), 89-94.

Dimoska, T., \& Trimcev, B. (2012). Competitiveness Strategies for Supporting Economic Development of the Touristic Destination. Procedia - Social and Behavioral Sciences, 44(local 279-288. https://doi.org/10.1016/j.sbspro.2012.05.031

Djakfar, M. (2017). Pariwisata Halal Persepektif Multidimensi. Uin-Maliki Press.

Fatwa Dewan Syariah Nasional. (2016). Fatwa Dewan Syariah Nasional-Majelis Ulama Indonesia: Pedoman Penyelenggaraan Pariwisata Berdasarkan Prinsip Syariah.

Ferdinand, A. (2006). Metode Penelitian Manajemen. Badan Penerbit Universitas Diponegoro.

Gabdrakhmanov, N. K., Biktimirov, N. M., Rozhko, M. V., \& Khafizova, L. V. (2016). Problems of development of halal tourism in Russia. Journal of Organizational Culture, Communications and Conflict, 20(Special Issue 2), 88-93.

Gwinner, K. P., Gremler, D. D., \& Bitner, M. J. (1998). Relational benefits in services industries: The customer's perspective. Journal of the Academy of Marketing Science, 26(2), 101-114. https://doi.org/10.1177/0092070398262002

Hadi, S. (2015). Metodologi Riset. Pustaka Pelajar.

Husein, U. (2005). Manajemen Riset Pemasaran dan Perilaku Konsumen. Gramedia. Jafari, J., \& Scott, N. (2014). Muslim world and its tourisms. Annals of Tourism Research, 44(1), 1-19. https://doi.org/10.1016/j.annals.2013.08.011

Jahja, Y. (2011). Psikologi Perkembangan. Kencana Prenada Media Grup.

Kinnear, T. C., \& Taylor, J. (2003). Riset Pemasaran (Translated by Thamrin (ed.); 3rd ed.). Erlangga.

Kotler, P., Bowen, J. T., \& Makens, J. C. (2014). Marketing for Hospitality and Tourism. 5 th edition. Pearson Prentice Hall.

Kotler, P., \& K., K. L. (2010). Manajemen Pemasaran Jilid I. Erlangga.

Mano, A., \& Costa, R. A. da. (2015). A Conceptual Model of the Antecedents and Consequences of Tourist Destination Image. Procedia Economics and Finance, 23(October 2014), 15-22. https://doi.org/10.1016/s2212-5671(15)00466-9

Mastercard \& Crescentrating. (2018). Mastercard-Crescentrating GMTI 2018 Global Muslim Travel Index 2018'. Journal of Materials Processing Technology.

Michalkó, G., Irimiás, A., \& Timothy, D. J. (2015). Disappointment in tourism: Perspectives on tourism destination management. Tourism Management Perspectives, 16, 85-91. https://doi.org/10.1016/j.tmp.2015.07.007

Morello, R. (2019). Morello, Robert. Tourism Promotion and Marketing, smallbusiness.chron.com. [Media online; 5 maret 2019]. https://smallbusiness.chron.com/tourism-promotion-marketing-57157.html. Smallbusiness.Chron.Com.

Nassar, M. A., Mostafa, M. M., \& Reisinger, Y. (2015). Factors influencing travel to Islamic destinations: An empirical analysis of Kuwaiti nationals. International Journal of Culture, Tourism, and Hospitality Research, 9(1), 36-53. 
https://doi.org/10.1108/IJCTHR-10-2014-0088

Niasari, Y. E. (2017). Pemetaan Potensi Objek Wisata Alam di Wilayah Kabupaten Pringsewu Tahum 2017. Universitas Lampung.

Nota Keuangan. (2020). Keuangan, Nota, 'Nota Keuangan (Beserta Rancangan Anggaran Pendapatan Dan Belanja Negara)*Financial Note (along with the Draft State Budget and Expenditure Budget)], 2019, 3. https://www.kemenkeu.go.id/informasi-publik/uu-apbn-dan-nota-keuangan/uuapbn-d. Www.Kemenkeu.Go.Id.

Nuri, E. K. (2018). Pengelolaan Wisata REligi Makam Sunan Kaliwungu Kendal (Perspektif Dakwah). In Journal of Materials Processing Technology. Universitas Islam Negeri Walisongo.

Paludi, S. (2017). Analisis Pengaruh Electronic Word of Mounth (e-WOM) terhadap Citra Destinasi, Kepuasan Wisatawan, dan Loyalitas Destinasi Perkampungan Budaya Betawi (PBB) Setu Babakan Jakarta Selatan. IBM Jakarta.

Parasuraman, A., Zeithaml, V. A., \& Berry, L. L. (1988). SERVQUAL: A Multi-item Scale For Measuring Consumer Perceptions of Service Quality. Journal of Retailing, 64(1), 12-40.

Pemerintah Provinsi Lampung. (2017). 'Laporan Kinerja Instansi Pemerintah ( LKIP ) Tahun 2017'*Government Agencies Performance Report (LKIP) 2017 '. Www.Pacurup.Go.Id.

Priyadi, U. (2016). Pariwisata Syariah (Prospek dan Perkembangan). UPP STIM YKPN.

Residendri.go.id. (2018). 'Capaian Sektor Pariwisata 3 Tahun Jokowi - Jk' [Tourism Sector Achievements 3 Years Jokowi - Jk], 2018.

Rinandiyana, L. R., Kusnandar, D. L., \& Bahren, B. (2018). Literasi Ict Dan Perilaku Hedonist Dalam Memilih Tempat Wisata Di Kalangan Kelas Menengah Sebagai Pengaruh Gaya Hidup. September, 1-13.

Sabon, V. L., Perdana, M. T. P., Koropit, P. C. S., \& Pierre, W. C. D. (2018). Strategi Peningkatan Kinerja Sektor Pariwisata Indonesia Pada ASEAN Economic Community. Esensi: Jurnal Bisnis Dan Manajemen, 8(2), 163-176. https://doi.org/10.15408/ess.v8i2.5928

Sach, I. (2010). Ilmu Pariwisata. Kementerian Kebudayaan REpublik Indonesia.

Satriana, E. D., \& Faridah, H. D. (2018). Wisata halal: perkembangan, peluang, dan tantangan. Journal of Halal Product and Research (JHPR) Vol., 01(02), 32-43.

Sekaran, U., \& Bougie, R. (2013). Research Methodsfor Bussines:A Skill Building Approach 6e. Wiley.

Soemitra, S., \& Ardianto, E. (2007). Dasar-Dasar Public Relations. Rosda.

Sudigdo, A., Khalifa, G. S. A., \& Abuelhassan, A. E. (2019). Driving Islamic Attributes, Destination Security Guarantee \& Destination Image to Predict Tourists'decision To Visit Jakarta. International Journal on Recent Trends in Business and Tourism, 3(1), 59-65.

Sugiyono. (2009). Metode Penelitian dan Bisnis. Alfabeta.

Sumiati, D. (2017). Intercultural Communication Based on Local Wisdom That Made the People of Bali Reject Sharia Tourism. Asian Journal of Media and Communication (AJMC), 1(2), 137-146.

Syahriza, R. (2014). Pariwisata Berbasis Syariah ( Telaah Makna Kata Sara dan Derivasinya dalam al- Qur' an ). Human Falah: Jurnal Ekonomi Dan Bisnis Islam, 1(2), 135-145. 
Tjipto, F., \& Gregorius, C. (2010). Service, Quality and Satisfacation. ANDI.

Urbanus, N., \& Febianti. (2017). 'Analisis Dampak Perkembangan Pariwisata Terhadap Perilaku Konsumtif Masyarakat Wilayah Bali Selatan.' Jurnal Kepariwisataan Dan Hospitalitas, 118-133.

Witt, S. F., \& Luiz, M. (1989). Tourism marketing and Management Handbook. UK: Prentice Hall International. Prentice Hall International.

Wu, S.-I., \& Zheng, Y.-H. (2014). The Influence of Tourism Image and Activities Appeal on Tourist Loyalty - A Study of Tainan City in Taiwan. Journal of Management and Strategy, 5(4), 121-135. https://doi.org/10.5430/jms.v5n4p121

Zumli, F. (2018). Peranan Sektor Pariwisata Terhadap Pendapatan Asli Daerah (PAD) di Provinsi Lampung. Universitas Islam Negeri Yogyakarta. 